\title{
PENERAPAN MODEL PEMBELAJARAN INKUIRI UNTUK MENINGKATKAN RASA INGIN TAHU SISWA PADA MATERI SISTEM REPRODUKSI KELAS XI MIA 8 SMA NEGERI 1 KARANGANYAR TAHUN PELAJARAN 2014/2015
}

\author{
IMPLEMENTATION OF INQUIRY LEARNING MODEL TO ENHANCE \\ STUDENT CURIOSITY ON REPRODUCTIVE SYSTEM AT GRADE XI MIA 8 \\ SMA NEGERI 1 KARANGANYAR ACADEMIC YEAR 2014/2015
}

\author{
RADEN RORO AVISA VERONICATAMA ${ }^{1)^{*}}$, MURNI RAMLI, DEWI PUSPITA SARI, \\ SRI ASTORINI ${ }^{2)}$ \\ ${ }^{1)}$ Program Studi Pendidikan Biologi \\ Fakultas Keguruan dan Ilmu Pendidikan \\ Universitas Sebelas Maret \\ Jl. Ir. Sutami 36 A, Surakarta, 57126, Indonesia \\ *Corresponding Author: avisa.vero@gmail.com \\ ${ }^{2)}$ SMA Negeri 1 Karanganyar, Jawa Tengah Indonesia
}

Manuscript received : 14 Juni 2016 Revision accepted: 15 Agustus 2016

\begin{abstract}
The research aimed to enhance student's curiosity by implementation of inquiry learning model on reproductive system at grade XI MIA 8 SMAN 1 Karanganyar academic year 2014/2015. This research was a Classroom Action Research that performed within 3 cycles. Each cycle consisted of 4 steps, there are planning, action, observation, and reflection. The subject is 31 students of grade XI MIA 8 SMAN 1 Karanganyar academic year 2014/2015. Data were obtained by observation, test, interview, and documentation. The data were analyzed by qualitative descriptive technique. To measure student's curiosity student's activity had been observed and questionaire had been distributed as well. Precycle showed that student's curiosity of grade XI MIA 8 SMAN 1 Karanganyar were low in each aspect, 1) Curiosity to get information and intellectual fact was 30,64\%, 2) Curiosity to accommodate the experiences with sense was $38,71 \%$,3) Desire to knowing more about the part of science which exist was $32,26 \%, 4)$ Curiosity to explore existing knowledge was $48,39 \%$.
\end{abstract}

keywords: inquiry learning model, curiosity

\section{PENDAHULUAN}

Pendidikan merupakan suatu upaya mengembangkan dan mengkonstruksi suatu peradaban untuk mewujudkan bangsa yang bermartabat. Memasuki abad ke-21, pendidikan di Indonesia dihadapkan pada sejumlah tantangan dan peluang. Salah satunya adalah mengubah pradigma pembelajaran menjadi lebih kreatif dan inovatif seiring dengan kemajuan teknologi yang semakin pesat. Rowson (2012) berpendapat bahwa kreativitas dapat ditingkatkan dengan menumbuhkan rasa ingin tahu yang besar pada setiap peserta didik. Apabila lebih dipahami, maka dapat dibangun cara untuk menumbuhkan rasa ingin tahu sebagai sebuah inovasi dalam proses belajar mengajar yang dapat meningkatkan mutu dan kualitas peserta didik.

Berdasarkan hasil observasi terhadap pembelajaran biologi di kelas XI MIA 8 SMA Negeri 1 Karanganyar tahun ajaran 2014/2015, proses pembelajaran belum terfokus kepada siswa (student centered) sehingga membuat siswa kurang terlibat aktif dalam pembelajaran. Siswa lebih banyak diam dan jarang bertanya, kurangnya rasa ingin tahu siswa dapat terlihat saat guru memberikan pertanyaan kepada siswa masih banyak siswa yang tidak menjawab dan lebih memilih diam meskipun soal yang diberikan sudah ada di buku pegangan siswa. Selain itu, siswa cenderung beranggapan bahwa biologi merupakan pelajaran yang butuh kemampuan menghapal yang tinggi. Apersepsi pada awal pembelajaran seharusnya mampu memicu motivasi belajar, ketertarikan, dan rasa ingin tahu siswa mengenai pelajaran yang akan diberikan. Namun, dalam praktiknya guru memberikan apersepsi yang kurang memenuhi kriteria di atas, akibatnya diawal pembelajaran siswa cenderung tidak bersemangat.

Berdasarkan hasil observasi lanjutan siswa kelas XI MIA 8 SMAN 1 Karanganyar yang berjumlah 31 siswa terlihat keaktifan dan keingintahuan dalam proses pembelajaran yang masih belum maksimal. Kurangnya rasa ingin tahu siswa pada pembelajaran biologi dapat diketahui dari hasil pengamatan terhadap perilaku siswa di kelas. Terlihat dari keinginan siswa untuk memperoleh 
informasi baru terkait materi yang diberikan belum maksimal, yaitu siswa kurang antusias menjawab pernyataan dari guru maupun teman lain. Berdasarkan hasil pengamatan, sebanyak 8 siswa dari 31 siswa (25, $81 \%$ ) yang aktif bertanya kepada guru. Selain itu, kurangnya partisipasi siswa ketika menjawab pertanyaan dan mengungkapkan pendapat di dalam kelas juga dapat dibuktikan dengan hanya 10 siswa dari 31 siswa $(32,26 \%)$ yang aktif dalam mengungkapkan pendapat. Terlihat dari perhatian siswa dalam melakukan pengamatan visual, yaitu siswa belum maksimal dalam menggunakan beberapa indera untuk mengeksplorasi objek pengamatan, hanya 12 siswa dari 31 siswa $(38,71 \%)$ perhatian dalam melakukan pengamatan ketika praktikum. Terlihat dari usaha siswa untuk mendapatkan informasi lanjut pada setiap tugas yang diberikan hanya 15 siswa dari 31 siswa $(48,39 \%)$ yang mencatat dan membuat rangkuman pada saat guru memberikan penjelasan. Pada saat pembelajaran di kelas saat melakukan penyelidikan seperti membuat rumusan masalah, hipotesis, rancangan percobaan dan melakukan analisis data, terdapat 11 siswa dari 31 siswa $(35,48 \%)$ ikut aktif dalam menyalurkan ide serta memecahkan masalah.

Hasil observasi menunjukan bahwa sikap rasa ingin tahu siswa yang meliputi bertanya, partisipasi aktif dalam berpendapat, antusias dalam melakukan penyelidikan, perhatian dalam melakukan pengamatan dan berusaha mempeoleh informasi baru tergolong rendah. Rasa ingin tahu dapat tergolong tinggi jika memiliki tingkat rata-rata $56 \%$ dan tergolong rendah jika memiliki tingkat rata-rata $38 \%$ (Kang, Hsu, Krajbich, Lowenstein, Mcclure, Wang, \& Camerer, 2008). Hasil observasi juga diperkuat dengan keterangan dari guru yang menyatakan selama pembelajaran, perhatian dan keaktifan siswa kurang berkembang. Keingintahuan siswa terhadap materi yang diberikan belum maksimal. Ketika diberikan pembelajaran tentang materi yang baru, siswa enggan untuk berpendapat dan lebih memilih diam. Menurut penuturan siswa, keengganan siswa untuk berpendapat, bertanya ataupun menjawab pertanyaan guru karena siswa malu, takut, tidak tahu, dan bila ada hal-hal yang kurang jelas lebih memilih bertanya kepada teman yang lebih pandai. Menurut Nasoetion dalam Hadi dan Permata (2010), rasa ingin tahu adalah suatu dorongan atau hasrat untuk lebih mengerti suatu hal yang sebelumnya kurang atau tidak diketahui.

Litman (2004) juga menanambahkan bahwa rasa ingin tahu (curiosity) dapat didefinisikan sebagai keinginan untuk memperoleh informasi baru yang lebih kompleks. Rasa ingin tahu dapat muncul karena rasa penasaran dari ketidakpastian suatu informasi dan termotivasi untuk memperoleh informasi yang baru melalui kegiatan eksplorasi. Fungsi rasa ingin tahu adalah untuk belajar, mengeksplorasi, dan berpartisipasi langsung dalam kegiatan yang merangsang rasa ingin tahu untuk memperhatikan sesuatu (Kashdan, Rose, \& Fincham, 2009). Rasa ingin tahu dapat dianalisis berdasarkan cakupan info yang ingin diketahui. Menurut Berlyne (1954), terdapat 4 dimensi rasa ingin tahu, yaitu keingintahuan terhadap informasi atau fakta intelektual (epistemic curiosity), keingintahuan untuk mengakomodasi pengalaman melalui indra (perceptual curiosity), keingintahuan untuk mengenal lebih dalam bagian dari pengetahuan yang ada (spesific curiosity), dan keingintahuan untuk mengeksplorasi pengetahuan atau informasi (diversive curiosity) (Kashdan et al, 2009). Menurut penelitian RSA project, dimensi-dimensi rasa ingin tahu dapat saling berkaitan dan seseorang dapat memiliki empat dimensi pada berbagai titik dalam waktu tertentu, serta segala macam faktor seperti suasana hati, lingkungan, konteks, dan lain-lain (Rowson, 2012).

Rasa ingin tahu dapat berpengaruh besar dalam aktivitas belajar siswa. Litman (2004) berpendapat bahwa rasa ingin tahu telah melibatkan dua jenis reaksi yang berbeda terhadap hal baru, yaitu perasaan menyenangkan yang menarik (Curiosity Feeling Interesting) dan perasaan ketegangan terhadap ketidakpastian informasi (Curiosity Feeling Devripation). Siswa yang memiliki rasa ingin tahu yang tinggi terhadap biologi akan mempelajari materi tersebut dengan sungguh-sungguh, tertarik dengan kegiatan praktikum bahkan bersemangat menyelesaikan soal-soal latihan dan praktikum karena adanya daya tarik yang diperoleh dengan mempelajari biologi. Peran guru sangat penting dalam membangkitkan rasa ingin tahu siswa sehingga siswa lebih tertarik dalam mengikuti pelajaran di kelas.

Penyebab kurang berkembangnya rasa ingin tahu siswa kelas XI MIA 8 SMA Negeri 1 Karanganyar berdasarkan hasil observasi kemungkinan disebabkan oleh beberapa faktor di antaranya, yaitu pembelajaran belum menggunakan strategi belajar yang bersifat student center yang dapat mendorong keaktifan siswa sehingga siswa cenderung pasif di kelas. Model pembelajaran yang digunakan kurang mengarahkan siswa pada pembelajaran yang bersifat kontekstual yang dapat memotivasi diri mereka sendiri sehingga kurang timbul rasa ingin tahu yang tinggi dan keberanian untuk bertanya terkait fenomena dan fakta ilmiah pada kehidupan sehari-hari. Menurut Suyanto (2013), keingintahuan siswa pada suatu hal tidak hanya membuahkan rasa penasaran dalam dirinya, akan tetapi rasa ingin tahu tersebut dapat memicu semangat belajar siswa untuk memperhatikan segala sesuatu yang diajarkan guru. Kondisi ini dapat membuat siswa lebih aktif sesuai dengan tujuan pembelajaran berbasis Kurikulum 2013. Seorang pengajar juga seharusnya mencari cara untuk memenuhi tuntutan pada sistem pendidikan di dunia yang berkembang dengan 
perubahan yang cepat, melalui pembelajaran yang mengaktifkan rasa ingin tahu siswa.

Pembelajaran untuk menstimulus rasa ingin tahu siswa dirancang dengan mengoptimalkan potensi yang dimiliki siswa, dengan harapan dapat membantu siswa dalam mengkontruksi pengetahuannya. Pembelajaran yang menitikberatkan pada keterlibatan siswa sehingga siswa aktif dalam membangun pengetahuannya dapat dilaksanakan dengan model pembelajaran active learning. Salah satu model pembelajaran active learning adalah model pembelajaran inkuiri. Model pembelajaran inkuiri dalam biologi merupakan model pembelajaran yang melibatkan siswa secara aktif karena inkuiri merupakan cara untuk mengembangkan kebiasaan berpikir siswa. Haury (1993) dalam artikelnya, Teaching Science Through Inquiry mengutip definisi yang diberikan oleh Alfred Novak, yaitu inquiry merupakan tingkah laku yang terlibat dalam usaha manusia untuk menjelaskan secara rasional fenomena-fenomena yang memancing rasa ingin tahu. Kegiatan tersebut bersumber dari keterampilan proses sains. Inkuiri telah menjadi istilah yang menonjol dalam pendidikan sains.

Pembelajaran inkuiri dirancang untuk mengajak siswa secara langsung ke dalam proses ilmiah ke dalam waktu yang relatif singkat (Trianto, 2011). Menurut National Research Council, inquiry meliputi berbagai aktivitas, di antaranya melakukan pengamatan, menjawab pertanyaan, mengkaji buku dan sumber informasi yang lain untuk melihat apa yang telah diketahui dari penemuan-penemuan yang sudah terbukti. Cara yang dilakukan, yaitu dengan mengumpulkan, menganalisis, menginterpretasikan data, menyusun jawaban, penjelasan dan memprediksi, serta mengkomunikasikan hasil penemuan (Sadeh \& Zion , 2012).

\section{METODE PENELITIAN}

Penelitian dilaksanakan di kelas XI MIA 8 SMA Negeri 1 Karanganyar. SMA Negeri 1 Karanganyar beralamat di Jalan AW. Monginsidi nomor 03, Karanganyar.

Data yang dikumpulkan dalam penerapan model pembelajaran inkuiri berupa informasi mengenai sikap rasa ingin tahu siswa yang meliputi beberapa aspek. Aspek rasa ingin tahu terdiri dari 4 aspek, yaitu epistemic curiosity, perceptual curiosity, spesific curiosity, dan diversive curiosity. Data yang digunakan pada penelitian ini berupa data hasil pengamatan atau observasi performance assesment curiosity siswa. Pengumpulan data rasa ingin tahu (curiosity) dilakukan dengan teknik non tes. Teknik non tes dilakukan dengan performance assesment (curiosity), angket, wawancara, dan observasi.

Penelitian yang digunakan adalah penelitian tindakan kelas (PTK). Menurut Arikunto (2008), penelitian tindakan kelas (PTK) merupakan pencermatan terhadap kegiatan belajar berupa sebuah tindakan yang sengaja dimunculkan dan terjadi dalam sebuah kelas secara bersama. Arikunto juga menambahkan bahwa PTK bertujuan untuk menanggulangi masalah dalam bidang pendidikan yang dilaksanakan di dalam kelas untuk meningkatkan kualitas pembelajaran dengan tindakan yang berulang (Ekawarna, 2013). Menurut Narawidjaja dalam Ekawarna (2013), penelitian tindakan kelas (PTK) terdiri dari siklus-siklus yang meliputi perencanaan (planning), pelaksanaan (acting), pengamatan (observing), dan refleksi (reflecting). Sumber data penelitian diperoleh dari data angket pengukuran rasa ingin tahu dalam bentuk penilaian, lembar observasi selama proses pembelajaran, lembar observasi keterlaksanaan sintak siswa dan guru, informasi hasil wawancara guru dan siswa yang dilakukan sebelum dan sesudah diterapkanya model pembelajaran inkuiri, serta dokumen kegiatan pembelajaran berupa silabus, RPP, lembar kerja siswa (LKS), dan dokumentasi kegiatan pembelajaran.

\section{HASIL DAN PEMBAHASAN}

Berdasarkan hasil penelitian, tingkat rasa ingin tahu siswa kelas XI MIA 8 SMA Negeri 1 Karanganyar dikatakan mengalami peningkatan setelah mengikuti pembelajaran dengan menggunakan model pembelajaran inkuiri pada materi Sistem Reproduksi Manusia. Peningkatan yang terjadi merupakan dampak dari pelaksanaan setiap sintaks model pembelajaran inkuiri. Peningkatan rasa ingin tahu tersebut dapat diuraikan sebagai berikut, yaitu rata-rata secara keseluruhan pada setiap siklus rasa ingin tahu mengalami peningkatan dari $49,11 \%$ menjadi $60,70 \%$ pada Siklus I, kemudian menjadi $70,94 \%$ pada Siklus II dan $77,03 \%$ pada Siklus III. Rentang peningkatan skor rasa ingin tahu dari pra siklus hingga Siklus III secara berturut-turut adalah 11,59\% dari Pra Siklus ke Siklus I, 10,24\% dari Siklus I ke Siklus II, dan 6,09\% dari Siklus II ke Siklus III. Grafik peningkatan rasa ingin tahu dari pra-siklus hingga Siklus III disajikan pada Gambar 1. 


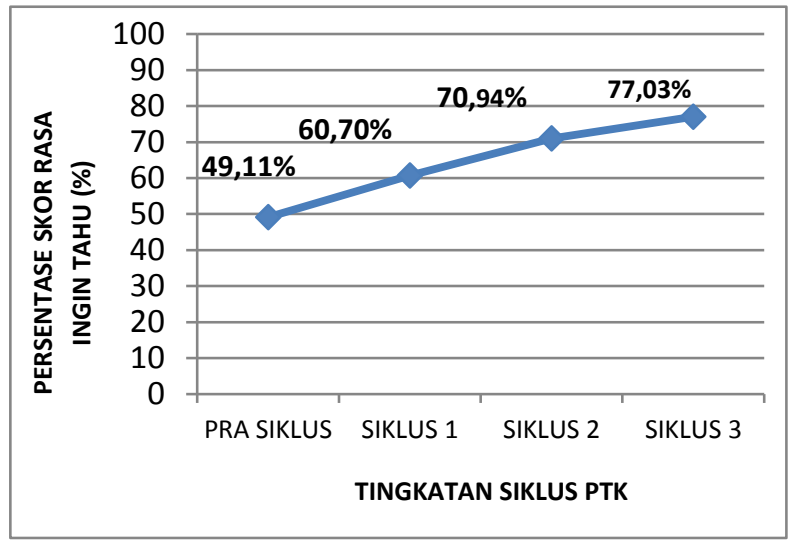

Gambar 1. Diagram Kenaikan Persentase Skor Rasa Ingin Tahu Pada Pra Siklus, Siklus I, Siklus II dan Siklus III

Peningkatan tiap siklus juga dipengaruhi oleh faktor latihan. Pembelajaran yang berlangsung, setiap siklus memiliki kesamaan tahapan pelaksanaan yang dimulai dari melakukan pengamatan hingga pada menyimpulkan hasil. Kegiatan yang selalu dilakukan berulang-ulang menyebabkan siswa maupun guru terbiasa dan terlatih dengan proses pembelajaran tersebut . Sependapat dengan Gutierez (2015) bahwa ketika sudah ada komitmen metode inkuiri yang digunakan dalam proses pembelajaran, maka menjadi jelas bahwa dalam peranannya guru membutuhkan dukungan kolegial dan kolaboratif dalam menerapkan metode pembelajaran dikelas. Dukungan yang dimaksud adalah keaktifan siswa dalam kegiatan pembelajaran sehingga meningkatkan rasa ingin tahu yang baik.

Guru secara aktif membimbing siswa untuk menyusun rumusan masalah dan membatasi masalah yang dapat dibuktikan kebenarannya melalui penyelidikan. Tidak hanya sedikit siswa yang kurang terlatih untuk merumuskan pertanyaan, tetapi mereka juga sering memiliki rasa percaya diri yang rendah ketika menyajikan ide-ide mereka, masalah, atau proyek-proyek (Delcourt et al, 2007). Pada sintaks ini siswa dituntut memiliki tingkat rasa ingin tahu yang tinggi sehingga mampu menyajikan ide-ide berupa pertanyaan atau menemukan masalah.

Rasa ingin tahu memiliki empat aspek, yaitu: (1) Epistemic curiosity, (2) Perceptual curiosity, (3) Specific curiosity, dan (4) Diversive curiosity. Setiap aspek rasa ingin tahu dapat menentukan dimensi rasa ingin tahu siswa. Skor capaian aspek rasa ingin tahu siswa siswa berdasarkan hasil observasi pada pra siklus, siklus 1,2 , dan 3 dapat dilihat pada Tabel 1.
Tabel 1. Rata-rata Skor Capaian Tiap Aspek Rasa Ingin Tahu Siswa

\begin{tabular}{lcccc}
\hline \multirow{2}{*}{ Dimensi } & \multicolumn{5}{c}{ Capaian aspek } \\
\cline { 2 - 5 } rasa ingin tahu & \multicolumn{2}{c}{ Pra } & \multicolumn{3}{c}{ Siklus } \\
\cline { 2 - 5 } & \multicolumn{1}{c}{ Siklus } & 1 & 2 & 3 \\
\hline Epistemic & 45.07 & 59.23 & 69.83 & 75.83 \\
\hline Perceptual & 51.73 & 60.54 & 71.54 & 78.34 \\
\hline Spesific & 47.81 & 59.51 & 67.97 & 76.15 \\
\hline Diversive & 55.36 & 63.54 & 74.43 & 77.82 \\
\hline
\end{tabular}

Peningkatan terjadi mulai dari siklus I, siklus II, dan siklus III baik dari tiap aspek rasa ingin tahu maupun rata-rata keseluruhan aspek.

Peningkatan rasa ingin tahu yang terjadi tiap siklus sepenuhnya dipengaruhi oleh penerapan model pembelajaran inkuiri. Mengajar siswa bagaimana cara untuk belajar dan bagaimana mengembangkan rasa ingin tahu merupakan tujuan pendidik pada umumnya dan guru sains pada khususnya (Sadeh, 2007). Selain itu metode inkuiri juga dapat mengembangkan keterampilan sains lainnya. Pembelajaran inkuiri adalah metode yang terkenal dan efektif untuk mengajar sains dan matematika. Mengembangkan rasa ingin tahu dalam sains dengan memberikan penjelasan mendalam terkait kurikulum, kerjasama, merupakan hasil dari pembelajaran yang berfokus pada penyelidikan dan sains interaktif (Arangala, 2013). Dalam kurikulum yang berkembang dimaksudkan juga bagaimana mengidentifikasi konten yang menjadi tujuan, bahwa pelajaran harus tercapai dan pertanyaan-pertanyaan yang membantu membimbing siswa fokus pada pembelajaran inkuiri akan membantu mereka mencapai tujuan pembelajaran (Thompson, 2008).

Kegiatan yang dilakukan dapat melatih rasa ingin tahu siswa secara efektif sehingga dapat meningkatkan keterampilan proses sains siswa hingga mencapai target di akhir siklus III yaitu sebesar $>70 \%$. Hasil penelitian berupa peningkatan rasa ingin tahu siswa yang diperoleh melalui pengukuran observasi dan angket serta didukung melalui wawancara dengan siswa dan guru.

Berdasarkan hasil wawancara dengan guru pada setiap akhir siklus, guru menyatakan bahwa melalui pembelajaran inkuiri memberikan dampak positif khususnya terhadap rasa ingin tahu siswa kelas XI MIA 8. Guru berpendapat bahwa sebagian besar siswa terlibat secara aktif dalam pembelajaran, mencari informasi terkait pembelajaran, sehingga tidak hanya diam dan pasif menerima materi melainkan juga dapat menggunakan sarana media informasi dengan baik, hal 
tersebut mengakibatkan rasa ingin tahu yang dimiliki masing-masing siswa dapat berkembang dan terlatih dengan baik. Pendapat guru didukung dengan pernyataan yang disampaikan oleh siswa melalui wawancara dengan siswa.

Hasil wawancara dengan beberapa perwakilan siswa diperoleh berbagai respon terhadap penerapan model pembelajaran inkuiri. Siswa sampel menyatakan bahwa pembelajaran yang diterapkan pada materi sistem reproduksi memberikan pengalaman lebih bagi siswa. Siswa merasa lebih antusias mengikuti pembelajaran, materi yang disampaikan lebih dapat dipahami, keterlibatan dalam melaksankan kegiatan pembelajaran lebih optimal. Siswa merasa kesulitan beradaptasi diawal pembelajaran, namun kemudian setelah kegiatan yang berkelanjutan siswa mampu mengikuti dan beradaptasi dengan tiap kegiatan dari model pembelajaran inkuiri mulai dari siklus I, II, dan III.

\section{KESIMPULAN}

Berdasarkan hasil penelitian dapat disimpulkan bahwa penerapan model pembelajaran inkuiri dapat meningkatkan rasa ingin tahu siswa dalam pembelajaran biologi di kelas XI MIA 8 SMA Negeri I Karanganyar tahun pelajaran 2014/2015.

\section{DAFTAR PUSTAKA}

Arangala, C. (2013). Developing Curiosity in Science With Service. Journal for Civic Commitment, 20, 1-10.

B.Wagner, C., \& Sundar, S. S. (2008). The Curiosity-Arousing Function of Anti-Drug Ads. The Open Communication Journal, 2, 43-59.

Banchi, H., \& Bell, R. (2008, October). The many Levels of Inquiry. Journal Science and Children, 26-29.

Delcourt, M., \& McKinnon, J. (2011). Tools For Inquiry: Improving Questioning in The Classroom. Learning Landscapes, 2(2), 145-159.

Gutierez, S. B. (2015). Collaborative Professional Learning Through Lesson Study : Indentifying the Challenges of Inquiry-Based Teaching. Issue in Education Research, 25(2), 118-133.

Hong Zang, M. I. (2008, August 21). Particle Swarm Optimization with Diversive Curiosity - An Endeavor to Enhance Swarm Intelengence. IAENG International Journal of Computer Science, 35(3).

Jepma, M., G.Verdonschot, R., Steenbergen, H. V., Rombouts, S. A., \& Nieuwenhuis, S. (2012). Neural Mechanism Underlying The Induction and Relief of Perceptual Curiosity. Frontier in Behavioal Neuroscience, 6(5), 1-9.

Maher, K. G. (2015). Specific Curiosity as a Cause and Consequence of Transformational Creativity. 260-267.

P.Arnone, M., V.Small, R., Chauncey, S. A., \& McKenna, H. P. (2011, February). Curiosity, Interest and Engagement in Technology Pervasive Learning Environtments : A New
Research Agenda. Education Research Tech Dev, 52, 181-189.

Pluck, Johnson, G. \&., \& Helen. (2011). Stimulating Curiosity to Enhance Learning. Education Science and Psychology, 2(19).

Robert P, C., A.Litman, J., \& Charles D, S. (2004). The Measurement of Perceptual Curiosity. Journal Personality and Individual Differences, 1127-1141.

Sadeh, Z. a. (2007). Curiosity and Open Inquiry Learning. Journal of Biologi Education, 41(4), 163-169.

Thompson, M. K. (2008). Scaffolding Science Inquiry Through Lesson Design.

Todd B.Kashdan, F. D. (n.d.). Curiosity and Exploration: Facilitating Positive Subjective Experiences and Personal Growth Opportunities. Journal Of Personality Assessment, 82(3), 291-305.

Towndrow, P. A., Ling, T. A., \& Venthan, A. M. (2008). Promote Inquiry Through Science Reflective Journal Writing. Eurasia Journal of Mathematics, Science and Technology Education, 4(3), 279-283.

Trna, J., Trnova, E., \& Sibor, J. (2012, November). Implementation Of Inquiry-Based Science Education In Science Teacher Training. Journal Educational and Instructional Studies in The World, 23(2)(4), 199-209.

Zayed, M., S.Vokos, Qaradawi, I., Said, Z., Kerr, T., \& Hinrich, R. (2014). Frostering Scientific Curiosity Through Strenghtening Teachers'Understanding of Energy and Inquiry. Frontiers in Mathematics and Science Education Research, 219-227. 